\title{
Development and Validation of HPTLC Method along with Forced Degradation Study for the Simultaneous Estimation of Azelastine Hydrochloride and Fluticasone Propionate in Nasal Spray Formulation using Design of Experiment Approach
}

\author{
Kalpana Govindbhai Patel*, Seena Ghanshyam Kumar Patel, Purvi Apurva Shah, Devang \\ Bhagvandas Tandel, Tejal Ricky Gandhi
}

Department of Quality Assurance, Anand Pharmacy College, Town Hall, Anand, Gujarat, INDIA.

\begin{abstract}
Objectives: The present research study focuses on the development of the highperformance thin layer chromatographic method using design of experiment approach for the simultaneous estimation of Azelastine hydrochloride and Fluticasone propionate along with forced degradation study. Methods: High performance thin layer chromatographic separation was performed on aluminium plates precoated with silica gel $60 \mathrm{~F}_{254}$ using toluene: chloroform: methanol (5: 4: 2, v/v/v) as optimized mobile phase. Azelastine hydrochloride and Fluticasone propionate were exposed to different forced degradation conditions. Full factorial design was applied on acid and base induced degradation and statistical analysis by ANOVA was performed with interpretation of various plots. The method was validated by determination of linearity, precision, accuracy, specificity and robustness according to $\mathrm{ICH}$ guidelines. Results: From different forced degradation conditions, major degradation was observed in acidic and basic condition. $\mathrm{R}_{f}$ for Azelastine hydrochloride and Fluticasone propionate was 0.33 and 0.53 at $232 \mathrm{~nm}$. The factor, temperature showed maximum \% contribution in acid and base induced degradation. Linear concentration range was 280-1680 $\mathrm{ng} / \mathrm{band}$ for Azelastine hydrochloride, $100-600 \mathrm{ng} / \mathrm{band}$ for Fluticasone propionate. The \% recovery ranged within 101.15$102.65 \%$ for Azelastine hydrochloride and $99.09-103.40 \%$ for Fluticasone propionate. The \% R.S.D values were less than $2 \%$ for both drugs indicating that the method is accurate, sensitive and precise. Conclusion: In summary, a novel, simple, accurate and reproducible high-performance thin layer chromatographic method was developed, for routine quality control testing of pharmaceutical formulation.
\end{abstract}

Key words: Azelastine Hydrochloride, Fluticasone Propionate, HPTLC, Degradation, DoE (Design of experiment), Validation.

\section{INTRODUCTION}

Azelastine Hydrochloride (AZH) and Fluticasone Propionate (FLU) spray is an antihistamine corticosteroid combination available as metered spray formulation for intranasal administration. AZH (Figure 1a), a secondgeneration $\mathrm{H}_{1}$-receptor antagonist, acts by inhibiting the release of histamine and other mediators involved in the allergic response. FLU (Figure 1b) a highly selective agonist at the glucocorticoid receptor results in anti-inflammatory and vasoconstriction effect. Literature survey revealed that AZH and FLU are official drugs in British Pharmacopoeia 2009, Indian Pharmacopoeia $2014^{2}$ and United States Pharmacopoeia 38 National formulary $33 .^{3}$

Prior art and thorough literature survey revealed several analytical methods for
Submission Date: 22-04-2019; Revision Date: 04-09-2019; Accepted Date: 10-11-2019

DOI: 10.5530/ijper.54.1.19 Correspondence: Dr. Kalpana Govindbhai Patel,

Professor, Department of Quality Assurance, Anand Pharmacy College, Town Hall, Anand-388001, Gujarat, INDIA.

Phone: +919825587547 E-mail: kalpana_jpatel@ yahoo.com

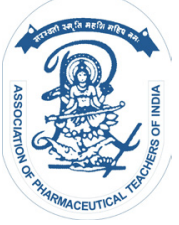

www.ijper.org 
the determination of FLU alone or in combinations including, UV spectrophotometry, ${ }^{4,5}$ HPLC, ${ }^{6-8}$ HPTLC $^{9}$ and ion pair HPLC. ${ }^{10}$ Several methods have also been reported for the determination of $\mathrm{AZH}$ alone or in combinations including, UV spectrophotometry, ${ }^{11}$ HPLC, ${ }^{12}$ HPTLC $^{13}$ and MS-EI ${ }^{14}$ methods. Stability indicating method is also reported for AZH using HPLC. ${ }^{15}$ Moreover, four UV spectrophotometric methods; first order derivative, ${ }^{16}$ double divisor ratio spectra, Ratio subtraction coupled with ratio difference and Mean centering ratio were reported for combination. ${ }^{17}$ Only one HPLC method for the cited mixture was reported in literature. ${ }^{18}$ However, the development of a High-performance Thin Layer Chromatographic (HPTLC) method for the simultaneous estimation of AZH and FLU in a combined dosage form has not yet been reported.

Hence, this manuscript is the first to describe the development and validation of HPTLC method as per the ICH guidelines ICH Q2 (R1) for the simultaneous estimation of AZH and FLU. A multivariate approach using an experimental design was used to study the effect of simultaneously varying several factors on the responses. ${ }^{19} 2^{3}$ full factorial designs were used to optimize acid and base induced degradation. A major advantage of developed HPTLC method is that several samples can be run simultaneously using a small quantity of mobile phase unlike HPLC, thus lowering the analysis time, sample clean up and cost per analysis. ${ }^{20}$

\section{MATERIALS AND METHODS}

\section{Materials}

Analytical pure samples of AZH and FLU were gifted as a gratis sample from Zydus Cadila Healthcare Limited, Ahmedabad, Gujarat, India. These samples were used without further purification. Nasal spray formulation, "DUONASE" (Cipla Ltd, Sikkim), was purchased from the local market containing AZH $(140 \mathrm{mcg})$ and FLU (50 mcg) per spray. All solvents and chemicals used were of analytical grade and purchased from S.D. Fine Chem. Ltd., Mumbai and Merck, Mumbai.

\section{Instrumentation}

A Hamilton microlitre syringe (Linomat syringe659.0014, Hamilton-Bonaduz Schweiz, Camag, Switzerland), silica gel $60 \mathrm{~F}_{254},(10 \times 10 \mathrm{~cm}, 100 \mu \mathrm{m}$ thickness; E. Merck, Darmstadt, Germany), Linomat 5 sample applicator (Camag, Switzerland), twin trough chamber $(20 \times 10$ $\mathrm{cm}$; Camag, Switzerland), TLC UV cabinet (Camag, Switzerland) and a TLC scanner 4 (Camag, Switzerland) operated by the WinCATS software (version 1.4.6, Camag, Switzerland) was used for research work. All drugs and chemicals were weighed on an electronic balance (AUW 220, Shimadzu, Japan).

\section{Preparation of standard solutions}

A stock solution of AZH and FLU was prepared by weighing accurately $10 \mathrm{mg}$ of drug followed by dissolution in methanol in $10 \mathrm{ml}$ volumetric flask and diluted up to the mark with methanol, to obtain a concentration of $1000 \mu \mathrm{g} / \mathrm{ml}$. This stock solution was appropriately diluted to make working standard solution as and when necessary.

\section{Chromatographic development procedure}

The samples were spotted in the form of bands having band width $8 \mathrm{~mm}$ with a microlitre micro syringe (Linomat syringe 659.0014, Hamilton-Bonaduz Schweiz, Camag, Switzerland) on precoated silica gel aluminium HPTLC plate $60 \mathrm{~F}_{254},(10 \mathrm{~cm} \times 10 \mathrm{~cm}), 100$ $\mu \mathrm{m}$ thickness; (E. Merck, Darmstadt, Germany) using a Camag Linomat V sample applicator (Switzerland). Linear ascending development was carried out in $20 \times$ $10 \mathrm{~cm}$ twin trough glass chamber (Camag, Switzerland). The mobile phase consisted of toluene: chloroform: methanol $(5: 4: 2 \mathrm{v} / \mathrm{v} / \mathrm{v})$. The optimized chamber saturation time before chromatographic development was $20 \mathrm{~min}$ at room temperature $\left(25^{\circ} \mathrm{C} \pm 2\right)$. The length of chromatographic run was $8 \mathrm{~cm}$ which took average 15 min to develop. Subsequent to the development; TLC plates were dried in a current of air with the help of an air dryer. Densitometry scanning was performed using Camag TLC scanner IV with WinCATS software (V 1.4.6.2002, Camag). All measurements were made in the reflectance-absorbance mode at $232 \mathrm{~nm}$, slit dimension ( $6.00 \times 0.30 \mathrm{~mm}$, micro), scanning speed $20 \mathrm{~mm} / \mathrm{s}$, data resolution $100 \mu \mathrm{m} /$ step, optical filter (second order), filter factor (Savitsky golay 7). The source of radiation was deuterium lamp emitting a continuous UV spectrum between 190 and $400 \mathrm{~nm}$.

\section{Forced degradation studies}

To evaluate the stability indicating property of the developed HPTLC method, standard drugs were subjected to forced degradation conditions like acid/base hydrolysis, oxidation and photo degradation. In all degradation studies, area \% of AZH and FLU and degradation product was considered and used for calculation.

\section{Acid-induced degradation study}

$10 \mathrm{mg}$ of AZH and FLU accurately weighed was transferred to $10 \mathrm{ml}$ volumetric flask individually and dissolved in $3 \mathrm{ml}$ methanol and diluted up to mark with hydrochloric acid ( $0.1 \mathrm{M}, 0.2 \mathrm{M}$ and $0.5 \mathrm{M}$ separately) to obtain final concentration of $1000 \mu \mathrm{g} / \mathrm{ml}$. The solutions 
were refluxed at $60^{\circ} \mathrm{C}$ and $70^{\circ} \mathrm{C}$ for $30 \mathrm{~min}$. Neutralized samples were directly applied to HPTLC plates and the chromatograms were run under optimized chromatographic conditions.

\section{Base-induced degradation study}

In base-induced degradation study, $10 \mathrm{mg}$ of $\mathrm{AZH}$ and FLU accurately weighed was transferred to $10 \mathrm{ml}$ volumetric flask individually and dissolved in $3 \mathrm{ml}$ methanol and diluted up to mark with sodium hydroxide $(0.1 \mathrm{M}$, $0.2 \mathrm{M}$ and $0.5 \mathrm{M}$ separately) to obtain final concentration of $1000 \mu \mathrm{g} / \mathrm{ml}$. The solutions were refluxed at $60^{\circ} \mathrm{C}$ and $70^{\circ} \mathrm{C}$ for $30 \mathrm{~min}$. Neutralized samples were directly applied to HPTLC plates and the chromatograms were run under optimized chromatographic conditions.

\section{Hydrogen peroxide-induced degradation study}

Hydrogen peroxide induced degradation was performed by accurately weighing $10 \mathrm{mg}$ of AZH and FLU, transferred to $10 \mathrm{ml}$ volumetric flask individually and diluted up to the mark with hydrogen peroxide $(0.3 \% \mathrm{v} / \mathrm{v}$ and 3 $\% \mathrm{v} / \mathrm{v}$ separately) to obtain final concentration of 1000 $\mu \mathrm{g} / \mathrm{ml}$. The resulting solutions were directly applied to HPTLC plates and the chromatograms were developed under optimized chromatographic conditions.

\section{Photo-degradation study}

For the photo-degradation study, the AZH and FLU standard powder $(10 \mathrm{mg}$ ) was exposed to UV light (in UV chamber) and sunlight for $24 \mathrm{~h}$. After that, appropriate dilutions were made in methanol to obtain final concentration of $1000 \mu \mathrm{g} / \mathrm{ml}$ and then analyzed under optimized chromatographic conditions.

\section{$2^{3}$ Full factorial Design for acid and base induced degradation}

Full Factorial design (FFD) $\left(2^{3}\right)$ with 8 experimental runs included 3 variables study at 2 levels. It was selected for forced degradation study. Among all degradation conditions, both the drugs in preliminary study showed more degradation under acidic and basic conditions and hence FFD was applied for studying acidic and basic degradation of both drugs.

Independent variables selected were strength of acid/ base, temperature and time while \% degradation of both drugs was selected as dependent variables. This choice was facilitated by the initial experiments. Factorial design and multiple regression equation were used to identify conditions for desired $0-25 \%$ degradation. $0.5 \mathrm{mg} / \mathrm{ml}$ of AZH and FLU in (A) hydrochloric acid was refluxed using different concentration at (B) different temperature $\left({ }^{\circ} \mathrm{C}\right)$ for $(\mathrm{C})$ different time duration (min). Two levels were chosen for each of A, B and C.
The high level (+1) for $\mathrm{A}, \mathrm{B}$ and $\mathrm{C}$ was $0.2 \mathrm{M}, 70^{\circ} \mathrm{C}$ and 30 min respectively and low level (-1) for $\mathrm{A}, \mathrm{B}$ and $\mathrm{C}$ was $0.1 \mathrm{M}, 60^{\circ} \mathrm{C}$ and $15 \mathrm{~min}$ respectively (Table 1 ). Similarly $0.5 \mathrm{mg} / \mathrm{ml}$ of $\mathrm{AZH}$ and FLU in Sodium hydroxide was refluxed using different (A) concentration at (B) different temperature $\left({ }^{\circ} \mathrm{C}\right)$ for $(\mathrm{C})$ different time duration (min). Two levels were chosen for each of $\mathrm{A}, \mathrm{B}$ and $\mathrm{C}$. The high level (+1) for $\mathrm{A}, \mathrm{B}$ and $\mathrm{C}$ was $0.5 \mathrm{M}, 70^{\circ} \mathrm{C}$ and 30 min respectively and low level (-1) for $A, B$ and $C$ was $0.2 \mathrm{M}, 60^{\circ} \mathrm{C}$ and $15 \mathrm{~min}$ respectively.

\section{Analysis of marketed formulation}

To determine the concentration of AZH and FLU in nasal spray formulation (label claim: 140 and $50 \mu \mathrm{g}$ per spray), $2.8 \mathrm{ml}$ ( $2800 \mu \mathrm{g}$ of AZH and $1000 \mu \mathrm{g}$ of FLU) was taken and transferred to $100 \mathrm{ml}$ beaker containing methanol and sonicated for $15 \mathrm{~min}$. The solution was filtered through Whatman filter paper $(0.45 \mu)$. This solution was transferred to $10 \mathrm{ml}$ volumetric flask and diluted up to mark to give a solution containing $280 \mu \mathrm{g} /$ $\mathrm{ml}$ of AZH and $100 \mu \mathrm{g} / \mathrm{ml}$ of FLU. Two microlitre of the filtered solution (560 ng/band of AZH and $200 \mathrm{ng} /$ band of FLU) was applied on the TLC plate followed by development and scanning. Analysis was repeated in triplicate.

\section{Method validation}

The method was validated in accordance with ICH guidelines Q2 (R1) for the evaluation of various parameters; linearity, precision, accuracy, LOD, LOQ, specificity and robustness. ${ }^{11}$ Linear relationship between peak area and concentration of AZH and FLU were evaluated over the concentration range expressed in $\mathrm{ng} / \mathrm{band}$ by making five replicate measurements in the concentration range of $280-1680 \mathrm{ng} / \mathrm{band}$ for AZH and 100 - $600 \mathrm{ng} / \mathrm{band}$ for FLU. Calibration plots were constructed by plotting the area of the peak versus the concentration of AZH and FLU using the method of ordinary least squares regression analysis. The linearity was further confirmed by Bartlett's test, to evaluate the homoscedasticity of variance. Precision of the developed method was evaluated by performing repeatability and intermediate precision studies. Repeatability on the same day was carried out by performing three replicates of three different concentration $(560,1120$ and 1680 ng of AZH and 200, 400, $600 \mathrm{ng}$ of FLU) and precision was expressed in terms of percent relative standard deviation (\%RSD). The intermediate precision was assessed by studying three different concentrations for three different days. The accuracy of method was ascertained by performing recovery at three levels $(50 \%$, $100 \%$ and $150 \%$ ). Recovery studies were carried out by 
spiking three different amounts of AZH standard (280, 560 and $840 \mathrm{ng}$ ) to the dosage form (560 ng/band) by standard addition method. Similarly, recovery studies were carried out by spiking three different amount of FLU standard (100, 200 and $300 \mathrm{ng}$ ) to the dosage form (200 ng/band) by standard addition method. Recovery studies were performed in triplicate. As per ICH guideline, limit of detection and quantification of the developed method was calculated from the standard deviation of the y-intercept and slope of the calibration curve of $\mathrm{AZH}$ and FLU using the formula, Limit of detection = $3.3^{*} \sigma / \mathrm{S}$. Limit of quantitation $=10^{*} \sigma / \mathrm{S}$. Where, " $\sigma$ " is $\mathrm{SD}$ of intercept "S" is Slope of calibration curve. The specificity of the method was ascertained by comparing peak purity of standard drug with formulation and degradation sample. The spot for AZH and FLU in sample and degradation studies was confirmed by comparing the $\mathrm{R}_{f}$ values and spectra of the sample spot with that of standard. Moreover, peak purity of AZH and FLU was assessed by comparing the spectra at three different levels, i.e., peak start $(S)$, peak apex $(M)$ and peak end (E) of the spot. As defined by the $\mathrm{ICH}$, the robustness of an analytical procedure refers to its capability to remain unaffected by small and deliberate variations in method parameters. 1) Mobile phase ratio $(2 \pm 0.1 \mathrm{ml}$ for one component), 2) Saturation time (20 $\pm 2 \mathrm{~min})$, 3) Distance travelled ( $8 \mathrm{~cm} \pm 2 \mathrm{~mm})$, 4) Wavelength change $(232 \pm 2 \mathrm{~nm})$ and the impact of small change was studied in terms of change in $\mathrm{R}_{f}$ and peak area and expressed as \%RSD.

\section{RESULTS AND DISCUSSION}

Both drugs appreciably absorbed at $232 \mathrm{~nm}$ and this wavelength was selected as the detection wavelength (Figure 2).

The optimized mobile phase (toluene: chloroform: methanol in 5:4:2 ratios resulted in good resolution with $\mathrm{R}_{f} 0.39$ for $\mathrm{AZH}$ and $\mathrm{R}_{f} 0.55$ for FLU (Figure 3).

\section{Forced degradation study}

The results of the forced degradation study of $\mathrm{AZH}$ and FLU using Toluene: chloroform: methanol [5:4:2, $\mathrm{v} / \mathrm{v} / \mathrm{v}$ ] as the mobile phase system are summarized in Table 1.

\section{Acid-induced degradation study}

AZH and FLU both were found to undergo acid degradation very rapidly. The reaction in $0.5 \mathrm{M} \mathrm{HCl}$ at $70^{\circ} \mathrm{C}$ under reflux for 30 min showed extensive degradation for AZH with additional peaks at $\mathrm{R}_{f}$ of $0.11,0.17,0.37$, $0.49,0.54,0.58$ respectively. For FLU, additional peaks were observed at $\mathbf{R}_{f}$ of $0.31,0.73$ respectively (Figure 4 ).

\section{Base-induced degradation study}

In base-induced degradation study, AZH and FLU showed additional peaks at $\mathrm{R}_{f}$ values $0.12,0.69,0.82$, 0.93 and $0.13,0.46,0.48,0.52,0.89$ respectively (Figure $5)$.

\section{Oxidative induced degradation study}

In the oxidative degradation study, it was found that both drugs were extremely liable to degradation. AZH exhibited degradation peaks at $\mathrm{R}_{f}$ values $0.13,0.35,0.71$ and 0.72 respectively and for FLU at $\mathrm{R}_{f}$ values $0.10,0.25$ respectively. The densitogram for the oxidative degradation study is shown in Figure 6.

\section{Photo-degradation study}

AZH and FLU both showed additional peaks at $\mathrm{R}_{f}$ value $0.22,0.45$ and $0.34,0.38$ respectively, in the sun light (Figure 7). And at $\mathrm{R}_{f}$ value $0.51,0.55$ and 0.35 respectively, in UV light (Figure 8).

\section{$2^{3}$ Full factorial design for acid and base induced degradation}

$\mathrm{AZH}$ and FLU were found to undergo acid and base induced degradation. The forced degradation experiments set up on the basis of factorial design were performed and the resulting samples were analyzed by HPTLC. Substantial degradation was observed in acidic and basic conditions. The experimental conditions and $\%$ degradation obtained for acid and base induced deg-

\begin{tabular}{|c|c|c|c|c|c|}
\hline \multicolumn{7}{|c|}{ Table 1: Summary of forced degradation study. } \\
\hline Sr. No. & Forced Degradation Study & \multicolumn{2}{|c|}{$\boldsymbol{R}_{\boldsymbol{f}}$ of drugs } & \multicolumn{2}{c|}{$\%$ degradation } \\
\hline & & AZH & FLU & AZH & FLU \\
\hline 1 & Acid $\left(0.5 \mathrm{M}, 70^{\circ} \mathrm{C} 30 \mathrm{~min}\right)$ & 0.30 & 0.52 & 40.66 & 24.47 \\
\hline 2 & Base $\left(0.5 \mathrm{M}, 70^{\circ} \mathrm{C}, 30 \mathrm{~min}\right)$ & 0.34 & 0.55 & 26.33 & 18.06 \\
\hline 3 & Oxidative $30 \mathrm{~min} 3 \% \mathrm{v} / \mathrm{v}$ & 0.30 & 0.55 & 10.54 & 10.63 \\
\hline 4 & Sun light $(12 \mathrm{~h})$ & 0.39 & 0.50 & 5.89 & 3.45 \\
\hline 5 & UV light $(254 \mathrm{~nm})(12 \mathrm{~h})$ & 0.39 & 0.52 & 2.67 & 1.9 \\
\hline
\end{tabular}




\begin{tabular}{|c|c|c|c|c|c|}
\hline \multirow[b]{2}{*}{ Run } & \multicolumn{3}{|c|}{ Factors } & \multicolumn{2}{|c|}{ Responses } \\
\hline & $\begin{array}{l}\text { Concentration } \\
\text { (M) }\end{array}$ & $\begin{array}{l}\text { Temperature } \\
\left({ }^{\circ} \mathrm{C}\right)\end{array}$ & $\begin{array}{l}\text { Time } \\
(\min )\end{array}$ & $\begin{array}{c}\% \text { Degradation of } \\
\text { AZH }\end{array}$ & $\begin{array}{c}\% \text { Degradation of } \\
\text { FLU }\end{array}$ \\
\hline 1 & 0.1 & 70 & 30 & 22.52 & 20.95 \\
\hline 2 & 0.1 & 60 & 15 & 10.01 & 3.3 \\
\hline 3 & 0.2 & 60 & 30 & 19.8 & 12.32 \\
\hline 4 & 0.2 & 70 & 15 & 33.7 & 26.69 \\
\hline 5 & 0.1 & 70 & 15 & 10.52 & 13.95 \\
\hline 6 & 0.1 & 60 & 30 & 13.49 & 3.73 \\
\hline 7 & 0.2 & 70 & 30 & 40.34 & 29.18 \\
\hline 8 & 0.2 & 60 & 15 & 12.9 & 5.71 \\
\hline
\end{tabular}

\begin{tabular}{|c|c|c|c|c|c|}
\hline \multirow[b]{2}{*}{ Run } & \multicolumn{3}{|c|}{ Factors } & \multicolumn{2}{|c|}{ Responses } \\
\hline & $\begin{array}{c}\text { Concentration } \\
\text { (M) }\end{array}$ & $\begin{array}{c}\text { Temperature } \\
\left({ }^{\circ} \mathrm{C}\right)\end{array}$ & $\begin{array}{l}\text { Time } \\
(\min )\end{array}$ & $\begin{array}{c}\% \text { Degradation } \\
\text { of AZH }\end{array}$ & $\begin{array}{c}\% \text { Degradation } \\
\text { of FLU }\end{array}$ \\
\hline 1 & 0.5 & 70 & 30 & 40.84 & 24.52 \\
\hline 2 & 0.5 & 60 & 15 & 10.25 & 5.26 \\
\hline 3 & 0.2 & 70 & 30 & 30.73 & 15.38 \\
\hline 4 & 0.2 & 60 & 30 & 13.28 & 6.58 \\
\hline 5 & 0.5 & 70 & 15 & 34.64 & 16.28 \\
\hline 6 & 0.2 & 70 & 15 & 22.4 & 11.32 \\
\hline 7 & 0.2 & 60 & 15 & 9.70 & 3.4 \\
\hline 8 & 0.5 & 60 & 30 & 19.58 & 9.18 \\
\hline
\end{tabular}

radation is as summarized in Table 2 and Table 3 respectively.

Pareto chart revealed that amongst all three factors, temperature had significant impact on $\%$ degradation of $\mathrm{AZH}$ and FLU, considering other variables. Pareto chart is used to estimate the importance of variable, Critical $t$-value, at $\alpha=0.05$ and 3 degrees of freedom were found to be 2.77645 for both responses. All factors whose absolute values of standardized effects above critical $t$-value are statistically significant. Pareto charts reveal that temperature and concentration showed significant impact on $\%$ degradation of $\mathrm{AZH}$ and $\%$ degradation of FLU (Figure 9 and Figure 11). Perturbation plots were constructed to evaluate the effect of the factors on the $\%$ degradation of both drugs. These graphs give the idea about how the response changes as each factor moves from its defined reference value, with all other factors held constant. Temperature (B) shows higher deviation from reference point compared to factor concentration (A) and time (C) for \% degradation of both the drugs in both acidic and basic conditions (Figure 10 and 12). The model was also validated with an Analysis of Variance (ANOVA) using the Design
Expert software, (Table 4). Significant effects had a $P$ value less than 0.05. An adequate precision, a measure of the signal (response) to noise ratio, greater than 4 is desirable and the obtained ratio for both drugs indicated an adequate signal. ${ }^{19,20}$ A coefficient of variation $(\%$ $\mathrm{CV}$ ), which measures the reproducibility of the model, was less than $10 \%$ and the adjusted R-square values were high, indicating a good relationship between the experimental data and those of the fitted models. Here, the adjusted $R^{2}$ values were well within the acceptable limit of $R^{2} \geq 0.80$, which indicated that the experimental data fitted polynomial equations well. ${ }^{21-23}$ The final equation, in terms of the actual components and factors, is as shown in Table 4. A positive value represents an effect that favors optimization, whereas a negative value indicates an inverse relationship between the factor and the response.

\section{Method validation}

AZH and FLU showed good correlation over a concentration range of 280-1680 ng/band and 100-600 $\mathrm{ng} / \mathrm{band}$ respectively with respect to peak area. The linearity of calibration curve and adherence of system to 


\begin{tabular}{|c|c|c|c|c|}
\hline Response & Polynomial equation model for $Y$ & $\% \mathrm{CV}$ & $\begin{array}{l}\text { Adequate } \\
\text { precision }\end{array}$ & $\begin{array}{l}\text { Adjusted } \\
\text { R-Square }\end{array}$ \\
\hline \multicolumn{5}{|c|}{ Acid-induced degradation } \\
\hline $\begin{array}{l}\% \text { Degradation } \\
\text { of } \mathrm{AZH}\end{array}$ & $\begin{array}{c}25.09+4.82^{*} \mathrm{~A} \text { Concentration }+8.81 * \mathrm{~B} \\
\text { temperature }+2.24^{*} \mathrm{C} \text { time }\end{array}$ & 15.13 & 11.824 & 0.8884 \\
\hline $\begin{array}{l}\% \text { Degradation } \\
\text { of FLU }\end{array}$ & $\begin{array}{c}14.48+4.00 \text { * } A \text { Concentration }+8.21 \text { * } B \\
\text { temperature }+2.07 \text { * } \mathrm{C} \text { time }\end{array}$ & 18.21 & 15.314 & 0.9333 \\
\hline \multicolumn{5}{|c|}{ Base-induced degradation } \\
\hline $\begin{array}{l}\% \text { Degradation } \\
\text { of } \mathrm{AZH}\end{array}$ & $\begin{array}{c}22.68+3.65^{*} \mathrm{~A} \text { Concentration }+9.48{ }^{*} \mathrm{~B} \\
\text { temperature }+3.43^{*} \mathrm{C} \text { time }\end{array}$ & 13.90 & 14.852 & 0.9274 \\
\hline $\begin{array}{l}\% \text { Degradation } \\
\text { of FLU }\end{array}$ & $\begin{array}{c}11.49+2.32 * A \text { Concentration }+5.39 * B \\
\text { temperature }+2.42 * \mathrm{C} \text { time }\end{array}$ & 19.22 & 12.976 & 0.9001 \\
\hline
\end{tabular}

\begin{tabular}{|c|c|c|}
\hline Parameters & AZH & FLU \\
\hline \multicolumn{3}{|l|}{ Linearity } \\
\hline Calibration range ${ }^{\mathrm{a}}(\mathrm{ng} / \mathrm{band})$ & $280-1680$ & $100-600$ \\
\hline Regression equation & $y=3.841 x+369.98$ & $y=6.091 x+312.03$ \\
\hline Correlation coefficient & 0.9998 & 0.9948 \\
\hline Standard deviation of slope & 0.024 & 0.021 \\
\hline Confidence limit of slope ${ }^{b}$ & $0.023-0.025$ & $0.020-0.022$ \\
\hline Standard deviation of intercept & 14.733 & 6.018 \\
\hline Confidence limit of intercept ${ }^{b}$ & $14.732-14.734$ & $6.017-6.019$ \\
\hline Bartlett's test ${ }^{\mathrm{c}}(\mathrm{X} 2)$ & 0.001882 & 0.0006371 \\
\hline \multicolumn{3}{|l|}{ Sensitivity } \\
\hline Limit of detection (ng/band) & 12.657 & 3.260 \\
\hline Limit of quantification(ng/band) & 38.354 & 9.880 \\
\hline \multicolumn{3}{|l|}{ Precision ${ }^{d}(\% R S D)$} \\
\hline Repeatability & $0.208-0.574$ & $0.317-0.506$ \\
\hline $\begin{array}{l}\text { Day } 1 \\
\text { Day } 2 \\
\end{array}$ & $\begin{array}{l}0.710-0.865 \\
0.710-0.987 \\
\end{array}$ & $\begin{array}{l}0.555-0.761 \\
0.555-0.983\end{array}$ \\
\hline Accuracy (\% recovery) ${ }^{e}$ & $101.15-102.65$ & $99.09-103.40$ \\
\hline
\end{tabular}

${ }^{a} \mathrm{n}=5$ replicates, ${ }^{\mathrm{b}}$ Confidence interval at $95 \%$ confidence level and four degree of freedom, ${ }^{\mathrm{c}}$ Calculated value $\chi^{2}$ less than critical value $\chi^{2}(0.05,4)=9.488,{ }^{d} n=3$ concentration/ 3 replicates, ${ }^{\mathrm{e}} n=3$ concentration/ 3 replicates.

Beer's law was evaluated by high value of correlation coefficient (Figure 13 and Table 5).

The precision of developed method was evaluated by repeatability and intermediate precision and was expressed as \%RSD of peak area. Repeatability and intermediate precision was at three different concentrations (Table 5), indicating acceptable precision in terms of repeatability of peak area measurement and sample application. The proposed method when used for evaluation of recovery at three concentrations levels, $50 \%, 100 \%$ and $150 \%$ after spiking with standard, showed percentage recovery between 101.15-102.65\% for AZH and $99.09-103.40 \%$ for FLU (Table 5). Limit of detection and limit of quantitation were found to be, for AZH; $12.657 \mathrm{ng} / \mathrm{band}$ and $38.354 \mathrm{ng} / \mathrm{band}$, for FLU; $3.260 \mathrm{ng} / \mathrm{band}$ and $9.880 \mathrm{ng} / \mathrm{band}$, indicating good sensitivity of the method (Table 5). The marketed formulation using the developed method, showed only one peak at $\mathrm{R}_{f}$ of 0.33 and 0.52 for $\mathrm{AZH}$ and FLU that were found to be at the same $\mathrm{R}_{f}$ for standard by the peak purity of AZH and FLU in marketed formulations comparing the spectra at peak start, peak apex and peak end positions of the spot, showed good correlation i.e., $r(S$, $\mathrm{M})=0.9997$ and $\mathrm{r}(\mathrm{M}, \mathrm{E})=0.9998$ for $\mathrm{AZH}$ and $\mathrm{r}(\mathrm{S}$, 


\section{Table 6: Robustness study by the proposed method.}

\begin{tabular}{c|c|c|c|c|}
\hline Drugs & Ratio & $R_{\mathrm{f}}$ & $\begin{array}{c}\text { Area } \pm \text { S.D }(\mathrm{ng} / \\
\text { band) }\end{array}$ & $\%$ RSD \\
\hline
\end{tabular}

Change in mobile phase ratio (Toluene: Chloroform: Methanol, 5: 4:2)

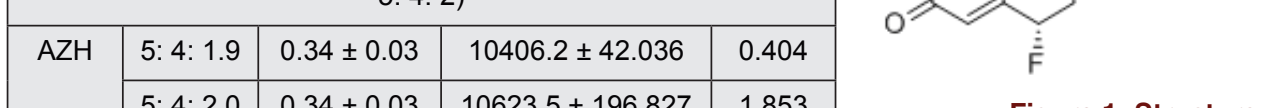

Figure 1: Structure of (a) AZH and (b) FLU.

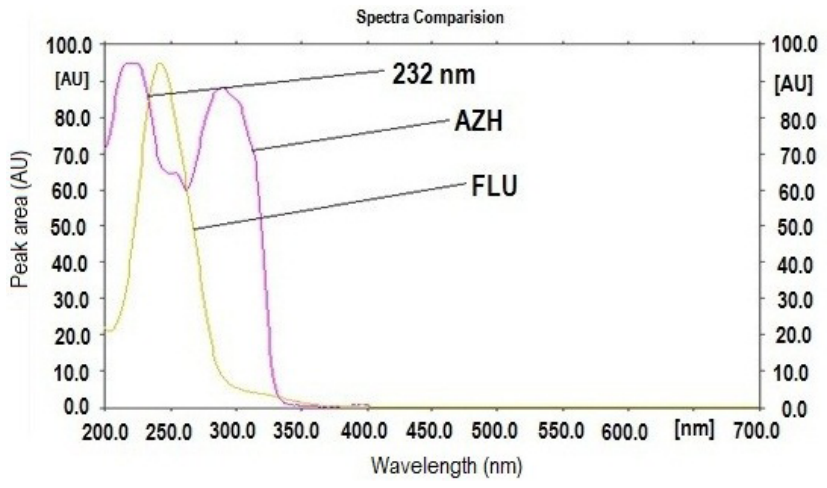

Figure 2: HPTLC Densitogram of AZH and FLU.

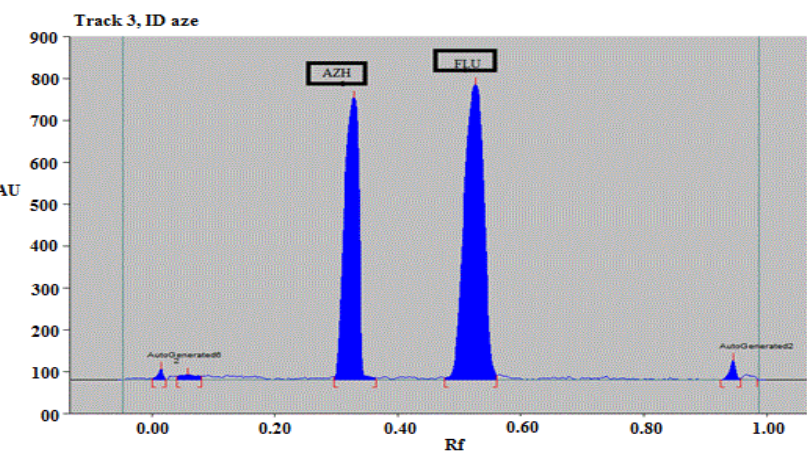

Figure 3: HPTLC densitogram of AZH and FLU using optimized mobile phase Toluene: chloroform: methanol (5:4:2, $\mathrm{v} / \mathrm{v} / \mathrm{v})$.

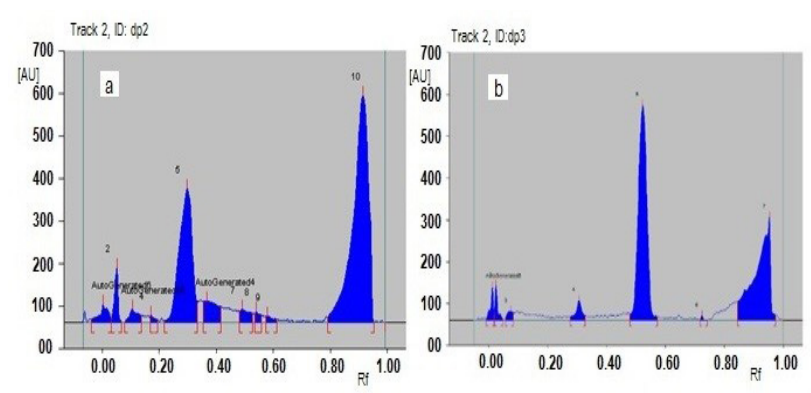

Figure 4: Acid-induced degradation of a) AZH b) FLU (0.5 M $\mathrm{HCl}, 70^{\circ} \mathrm{C}, 30 \mathrm{~min}$ ) showing $\mathrm{R}_{f}$ at 0.30 for $\mathrm{AZH}$ and 0.52 for FLU.

$\mathrm{M})=0.9992$ and $\mathrm{r}(\mathrm{M}, \mathrm{E})=0.9996$ for FLU (Figure 14). Similarly, the peak purity of AZH and FLU in degradation samples comparing the spectra at peak start, peak apex and peak end positions of the spot, showed good correlation i.e., $\mathrm{r}(\mathrm{S}, \mathrm{M})=0.9994$ and $\mathrm{r}(\mathrm{M}, \mathrm{E})=0.9998$ 

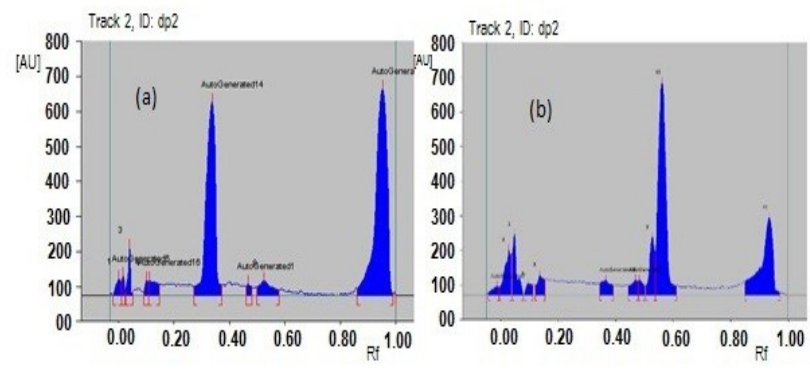

Figure 5: Base-induced degradation of (a) AZH and (b) FLU $\left(0.5 \mathrm{M} \mathrm{NaOH} 60^{\circ} \mathrm{C} 30 \mathrm{~min}\right.$ ) showing $R_{f}$ at 0.34 for $A Z H$ and 0.56 for FLU.
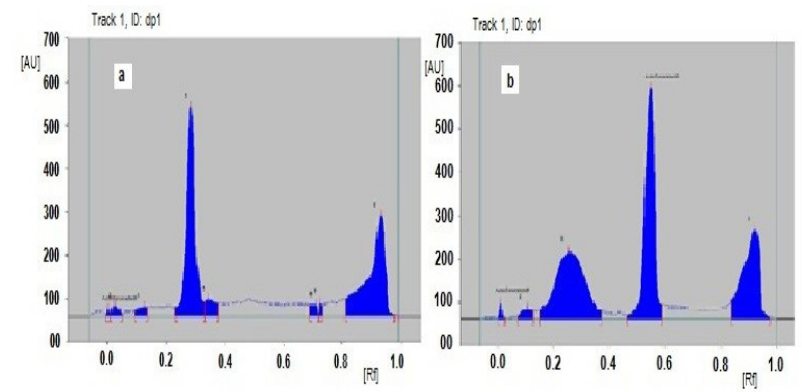

Figure 6: $3 \% \mathrm{v} / \mathrm{v} \mathrm{H}_{2} \mathrm{O}_{2}$ exposures at R.T for $30 \mathrm{~min}$ a) $\mathrm{AZH}$ and b) FLU showing $\mathrm{R}_{f}$ at $\mathbf{0 . 3 0}$ for $\mathrm{AZH}$ and 0.55 for FLU.
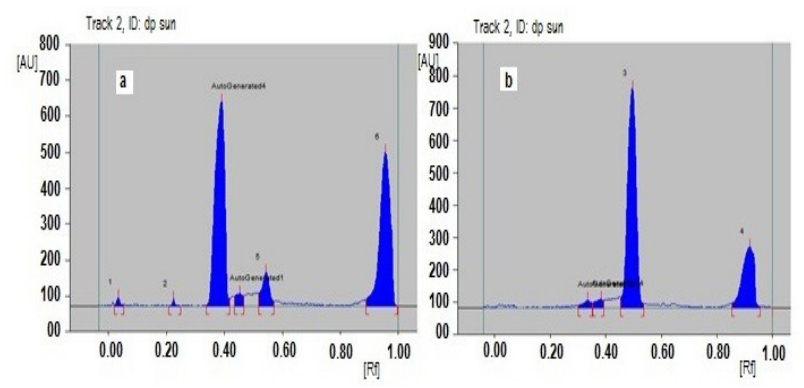

Figure 7: Sun light induced degradation for $24 \mathrm{~h}$ (a) AZH and (b) FLU showing $\mathrm{R}_{f}$ at 0.39 for $\mathrm{AZH}$ and 0.50 for FLU.
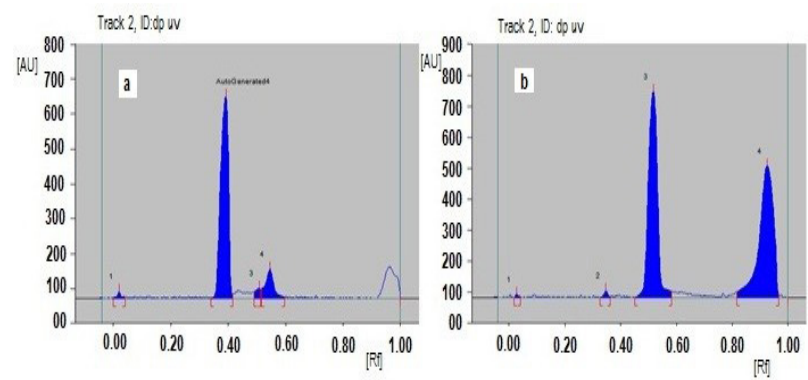

Figure 8: UV light induced degradation for $24 \mathrm{~h}$ (a) AZH and (b) FLU showing Rf at 0.39 for AZH and 0.52 for FLU.

for $\mathrm{AZH}$ and $\mathrm{r}(\mathrm{S}, \mathrm{M})=0.9997$ and $\mathrm{r}(\mathrm{M}, \mathrm{E})=0.9998$ for FLU (Table 5). The degradation sample also showed only one peak at $\mathrm{R}_{f}$ of 0.34 and 0.55 for $\mathrm{AZH}$ and FLU

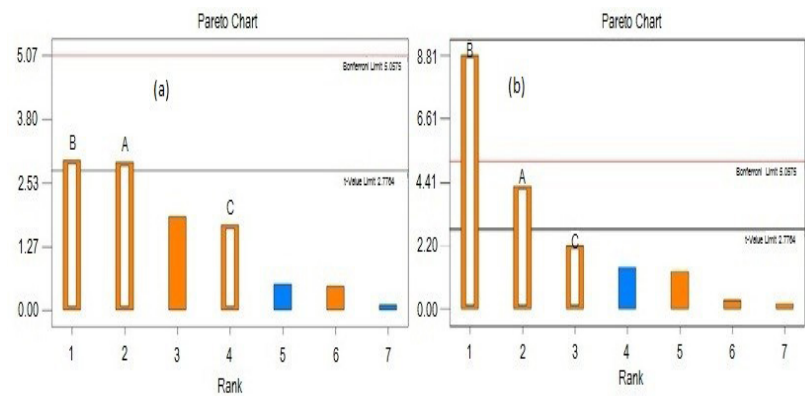

Figure 9: Pareto chart showing effect of factor on acid-induced degradation (a) $B>A>C$ for \% degradation of $A Z H$ (b) $B>A>C$ for $\%$ degradation of FLU.
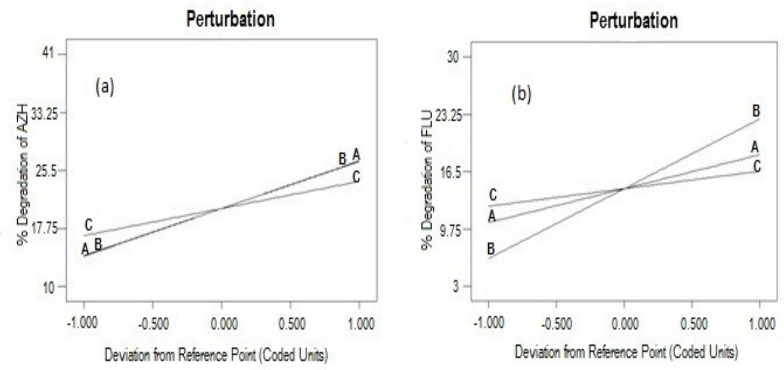

Figure 10: Perturbation graph showing the effect of each factor $\mathrm{A}, \mathrm{B}$ and $\mathrm{C}$ on acid-induced degradation on $\%$ degradation of both drugs (a) AZH and (b) FLU.

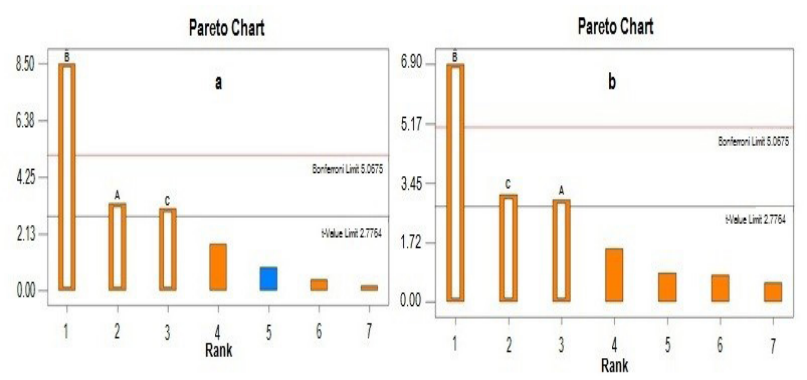

Figure 11: Pareto chart showing effect of factor on baseinduced degradation a) $B>A>C$ for $\%$ degradation of $A Z H$ b) $\mathrm{B}>\mathrm{C}>\mathrm{A}$ for $\%$ degradation of FLU.
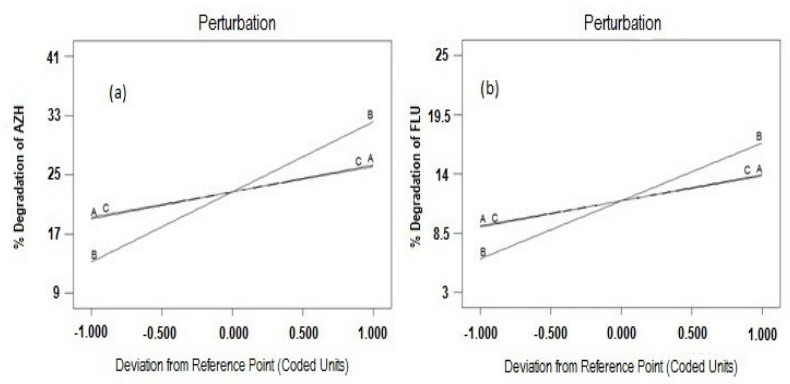

Figure 12: Perturbation graph showing the effect of each factor $\mathrm{A}, \mathrm{B}$ and $\mathrm{C}$ on base-induced degradation on $\%$ degradation of (a) AZH (b) FLU.

(Figure 15). Deliberate change in different parameters like mobile phase composition, saturation time, distance travel, wavelength scan, showed \% relative standard 


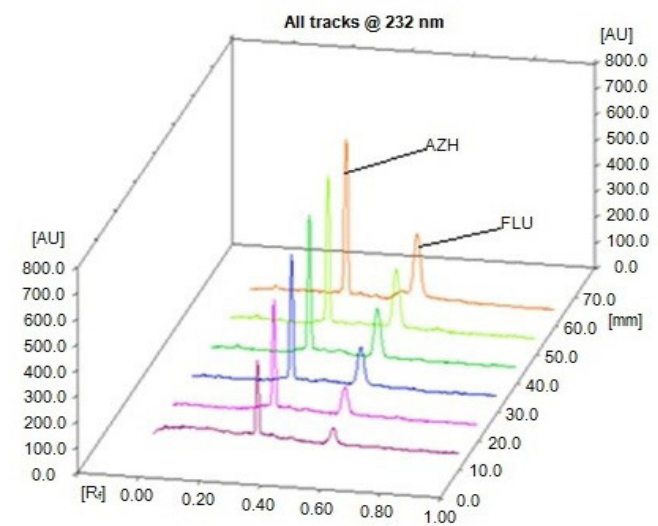

Figure 13: 3D Densitogram showing linearity of AZH (280 $1680 \mathrm{ng} / \mathrm{band})$ and FLU (100 - $600 \mathrm{ng} / \mathrm{band})$.
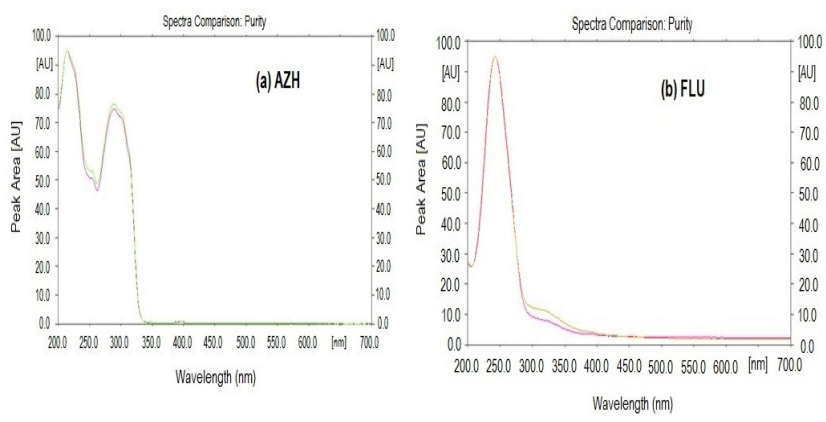

Figure 14: Overlain spectra of pharmaceutical formulation with standard (a) AZH and (b) FLU showing peak purity.
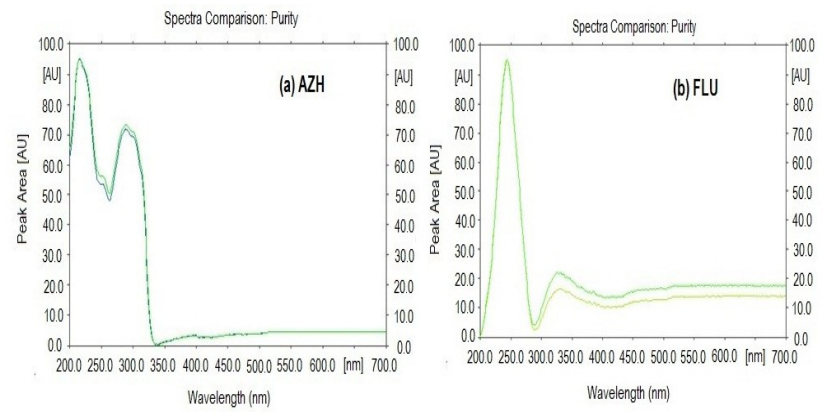

Figure 15: Overlain spectra of acid-induced degradation samples with standard (a) AZH and (b) FLU showing peak purity.

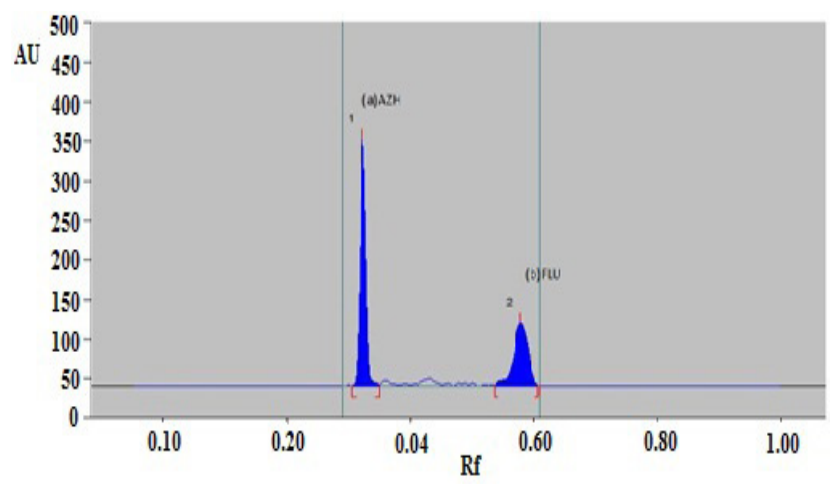

Figure 16: Chromatogram of pharmaceutical formulation with concentration of $560 \mathrm{ng} / \mathrm{band}$ of AZH and $200 \mathrm{ng} / \mathrm{band} \mathrm{FLU}$ with label claim of $140 \mu \mathrm{g}$ of $A Z H$ and $50 \mu \mathrm{g}$ of FLU. deviation of peak area less than $2 \%$, indicates that the method is robust (Table 6). Results presented in Table 6 indicate that the selected factors remained unaffected by small variation of these parameters.

\section{Analysis of pharmaceutical formulation}

The nasal spray formulation using the developed method, showed separate peak at $\mathrm{R}_{f} 0.32$ for $\mathrm{AZH}$ and 0.58 for FLU indicating no interference of the excipient and showed mean \%recovery of $105.2 \pm 1.27$ and 96.02 \pm 1.19 for AZH and FLU respectively. (Figure 16).

\section{CONCLUSION}

HPTLC method using DoE approach was developed and validated for the determination of AZH and FLU. The developed method was found to be simple, rapid, specific, sensitive and suitable for the determination of AZH and FLU. The proposed method was applied for the analysis of AZH and FLU in nasal spray formulation. Additional advantages include high sample throughput, short system equilibration time, minimum mobile phase requirement and no prior requirement of degassing and filtration of mobile phase. Acid-induced degradation resulted in $40.66 \%$ degradation of $\mathrm{AZH}$ and $24.77 \%$ of $\mathrm{FLU}$ with $0.5 \mathrm{M} \mathrm{HCl}$ at $70^{\circ} \mathrm{C}$ for $30 \mathrm{~min}$. Similarly, base induced degradation resulted in $26.33 \%$ degradation of $\mathrm{AZH}$ and $18.06 \%$ degradation of FLU with $0.5 \mathrm{M} \mathrm{NaOH}$ at $70^{\circ} \mathrm{C}$ for $30 \mathrm{~min}$. Moreover, in oxidative and photolytic conditions, degradation was less. Forced degradation study showed that all degradation products were well separated from AZH and FLU, hence the method can be employed individually for forced degradation study for both drugs.

\section{ACKNOWLEDGEMENT}

The authors would like to thank, Zydus Cadila Healthcare Limited, Ahmedabad for providing gratis sample of standard AZH and FLU.

\section{CONFLICT OF INTEREST}

The authors declare no conflict of interest.

\section{ABBREVIATIONS}

AZH: Azelastine hydrochloride; FLU: Fluticasone propionate.

\section{REFERENCES}

1. British Pharmacopoeia 2009. Published by British Pharmacopoeia Commission. 2009;1:194-5, 904-6. 
2. Indian Pharmacopoeia 2014. Ministry of Health and Family Welfare. Published by Indian Pharmacopoeia Commission. 2010;1114-5, 1811-2.

3. United States Pharmacopoeia 2015. USP 38 and NF 33. Published by United state Pharmacopoeia Commission. 2015;2:2338-9, 2579-3578.

4. Kulkarni RR, Phadtare DG, Saudagar RB. UV spectrophotometric Method development and validation of Fluticasone propionate. Asian J Pharm Sci. 2016;6(2):135-8.

5. Kondawar MS, Shah RR, Waghmare JJ, Malusare MK, Shah ND. UV spectrophotometric method for simultaneous estimation of salmeterol xinafoate and fluticasone propionate in bulk and dosage form. Inter J Pharm Tech Res. 2011;3(3):1801-6.

6. Gowekar NM, Wadher SG. Simultaneous estimation of formoterol fumarate dihydrate and fluticasone propionate in dry powder inhalation formulation by RP-HPLC. Int J Pharm Tech Res. 2016;9(1):164-70.

7. Malik K, Kumar D, Tomar V, Soni L. Simultaneous quantitative determination of formoterol fumarate and fluticasone propionate by validated reversedphase HPLC method in metered dose inhaler. Der Pharmacia Sinica. 2011;2(6):77-84.

8. Dave HN, Makwan AG, Suhagia BN. Validated reversed phase high performance liquid chromatographic method for determination of three novel steroids in bulk and pressurized metered - dose commercial preparations using a common mobile phase. Inter $\mathrm{J}$ of Applied Science and Engineering. 2013;11(2):125-35.

9. Kasaye L, Hymete $\mathrm{H}$, Mohamed A. HPTLC-densitometric method for simultaneous determination of salmeterol xinafoate and fluticasone propionate in dry powder inhalers. Saudi Pharm J. 2010;18(3):153-9.

10. Raval PP, Dave JB, Joshi MP, Solanki BK. Estimation of fluticasone propionate in nasal preparation and in combination with formoterol fumarate in inhalation preparation. World J Pharm Pharm S. 2014;3(6):1148-60.

11. Gouda AA, Sheikh RE, Saied HE. Extractive spectrophotometric determination of azelastine hydrochloride in pure form and pharmaceutical formulations. Can Chem Trans. 2015;3(1):29-41.

12. Kapadnis RK, Baviskar SR, Mahajan SK. Assay method development and validation for simultaneous estimation of mometasone furoate and azelastine hydrochloride by RP-HPLC. Asian J Biochem and Pharm Res. 2014;4(4):319.

13. Elobieta W, Krystyna CK, Elobieta K, Mazurek A. Identification and determination of ketotifen hydrogen Fumarate, azelastine hydrochloride, dimetindene maleate and promethazine hydrochloride by densitometric method. Acta Pol Pharm. 2013;70(6):951-9.
14. Abdel-Razeq SA, Salama NN, Abdel-Atty A, El-Kosy N. Thermo analytical study and purity determination of azelastine hydrochloride and emedastine difumarate. Pharm Anal Acta. 2012;3(8):1-4.

15. Rania N, Shaheny E, Yamada K. Stability study of antihistamine drug azelastine $\mathrm{HCl}$ along with kinetic investigation and identification of new degradation products. J Anal Sci Technol. 2014;30(6):691-7.

16. Patel R, Patel B, Thakkar H, Patel P, Patel N, Patel S. Development and validation of first order derivative spectrophotometric methods for simultaneous estimation of fluticasone propionate and azelastine hydrochloride in nasal spray preparations. Inventi Pharm Analysis and Quality Assurance. 2013;904:13

17. Merey H, El-Mosallamy S, Hassan N, El-Zeany B. Simultaneous determination of fluticasone propionate and azelastine hydrochloride in the presence of pharmaceutical dosage form additives. Spectrochim Acta. 2016;160:1-27.

18. Prathap B, Jegannath S, Swathikrishna KV, Priyanka V, Rajeshwari G, Gobalakrishnan P. Method development and validation for simultaneous estimation of Azelastine and Fluticasone in pharmaceutical dosage form by RP-HPLC. Asian J of Pharm Analysis and Medicinal Chem. 2016;4(2):79-87.

19. Patel K, Shah P, Gandhi T. Stability-Indicating High-Performance Thin-Layer Chromatographic Method for the Estimation of Ambroxol Hydrochloride and Doxofylline in Pharmaceutical Formulations Using Experimental Design in Robustness Study. J of Planar Chromatography. 2016;29(2):1-9.

20. Sivakumar T, Manavalan R, Valliappan K. Global optimization using derringer's desirability function: Enantio selective determination of ketoprofen in formulation and biological matrices. Acta Chromatographica. 2007;19:2947.

21. Solanki TB, Shah PA, Patel KG. Central Composite Design for validation of HPTLC method for simultaneous estimation of Olmesartan medoxomil, Amlodipine besylate and Hydrochlorothiazide in tablets. Indian J Pharm Sci. 2014;76(3):179-87.

22. Mustafa G, Ahuja A, Baboota S, Ali J. Box-Behnken supported validation of stability-indicating High Performance Thin-layer Chromatography (HPTLC) method: An application in degradation kinetic profiling of ropinirole. Saudi Pharm J. 2013;21(1):93-102.

23. Shah P, Patel J, Patel K, Gandhi T. Development and validation of an HPTLC method for the simultaneous estimation of Clonazepam and Paroxetine hydrochloride using a DOE approach. $\mathrm{J}$ of Taibah University for Science. 2016;1-12.

\section{SUMMARY}

Allergic rhinitis, also known as hay fever, is a type of inflammation in the nose which occurs when the immune system overreacts to allergens in the air. Azelastine hydrochloride as antihistaminic and Fluticasone propionate as glucocorticoid in nasal spray formulation in combination is available for the treatment of seasonal allergic rhinitis. HPTLC aluminium plates precoated with silica gel $60 \mathrm{~F}_{254}$ was used as stationary phase for optimization of mobile phase. $\mathrm{R}_{f}$ for both the drugs showed good resolution at $232 \mathrm{~nm}$ using optimized mobile phase; Toluene: chloroform: methanol in the ratio of 5: 4: 2, v/v/v. AZH and FLU were exposed to different forced degradation conditions. Full factorial design was applied on acid and base induced degradation and statistical analysis by ANOVA was performed with interpretation of various plots. From different forced degradation conditions, major degradation was observed in acidic and basic condition. The factor, temperature showed maximum $\%$ contribution in acid and base induced degradation. The method was validated by linearity, precision, accuracy, specificity and robustness according to ICH guidelines. Thus, specific, accurate and precise HPTLC method was developed and successfully applicable for estimation of both drugs loaded in nasal spray formulation. 


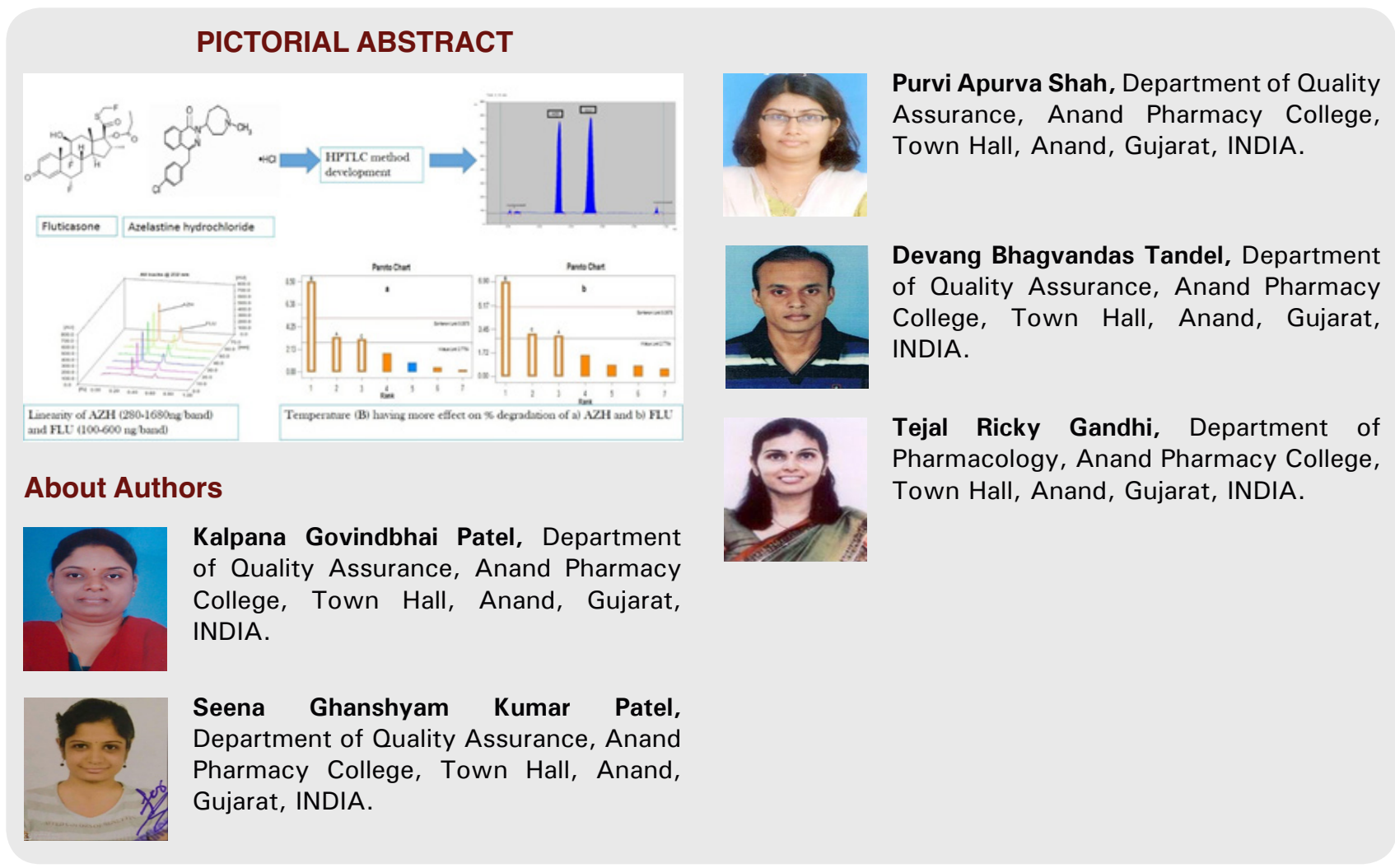

Cite this article: Patel KG, Patel SG, Shah PA, Tandel DB, Gandhi TR. Development and Validation of HPTLC Method along with Forced Degradation Study for the Simultaneous Estimation of Azelastine Hydrochloride and Fluticasone Propionate in Nasal Spray Formulation using Design of Experiment Approach. Indian J of Pharmaceutical Education and Research. 2020;54(1):155-65. 